\title{
TEACHERS' SELF-EFFICACY: EFFECTIVE INDICATOR TOWARDS STUDENTS' SUCCESS IN MEDIUM OF EDUCATION PERSPECTIVE
}

\author{
Mehboob UI Hassan \\ University of the Punjab, Pakistan \\ E-mail: hassanbhattig@hotmail.com
}

\begin{abstract}
School is a subculture of any society having different educational diversity. This diversity affects on teachers and students achievements; pillars of teaching learning process. Teachers have great concerns towards students' success. They deliver plethora of information to improve students' achievements. Present quantitative ex-post-facto research was framed to explore the effect of teachers' self-efficacy on students' achievement scores applying multilingual instructions for students' success on sample of randomly selected 1100 male respondents; 300 secondary school teachers and 800 students of District Kasur, of Lahore Division. Data from teachers were collected by administering long form of Teachers' Self-Efficacy Scale whereas students' achievement scores were obtained from annual gazette notification of Board of Intermediate and Secondary Education, Lahore. Cronbach's Alpha Score was applied to confirm instrument's reliability .851. Normality of the data were confirmed by calculating Shapiro-Wilk's test. Findings of regression analysis depict that overall teachers' self-efficacy has affected $65 \%$ whereas students' engagement $59 \%$, educational strategies $60 \%$, classroom management $59 \%$ and teachers' medium of education has affected $30 \%$ on students' achievement scores. Present research recommends that Government structure teachers' self-efficacious believes through providing training, conducting workshops before joining teaching professions and ensuring certificates; once teachers' confidence structure, less possible to alter to obtained desired achievements during teaching learning process. Furthermore, it is dire need to implement single medium of instructions; English / Urdu in public sector secondary schools of Punjab as bilingual medium of education have been remaining one of the barrier that lead students towards poor achievements.
\end{abstract}

Keywords: achievement scores, classroom management, instructional strategies, education medium, secondary level, self-efficacy, students'engagement.

\section{Introduction}

Teachers provide plethora of information for students' better success. They enlighten facts, impart instructions and transfer knowledge focusing confidence; self-efficacy among students for their educational achievements (Adu, Tadu, \& Eze, 2012; Bandura, 2002; Duncan \& McKeachie, 2005; Klassen \& Chiu, 2010; Mclnerney, 2005; Pintrich \& Schunk, 2002; Yough, 2019) in diverse medium of educational perspective. Self-efficacy is considered as individual's capability used to complete assigned tasks facing certain situations (Bandura, 1997). It refers to human talents about their hidden potentials to complete assigned goals and ability to do something (Axtell \& Parker, 2003). Self-efficacy is predicted in diversity of ways to measure one's abilities, developmental studies and entire achievement (Adu, Tadu, \& Eze, 2012).

Notion self-efficacy has strapping roots with social cognitive theory put forward by Bandura (Pajares \& Graham, 1999). Theory states that individual's working is based on 
PROBLEMS

OF EDUCATION IN THE $21^{\text {st }}$ CENTURY Vol. 77 , No. 5, 2019

his/her cognitive, behavioral, personal and environmental factors. Environmental changes automatically bring variations in human behaviors that are interlinked with their motivational and social determination (Crothers, Hughes, \& Morine, 2011), embodied triadic reciprocal model (Wood \& Bandura, 1989). This developmental behavior moves towards model of human observation and shapes symbolic formation towards new behavioral model (Tschannen-Moran, Hoy, \& Hoy 1998; Schunk \& Pajares, 2005; Schunk \& Zimmerman, 2006; Zimmerman, 2008). Human beings less react to environmental influence but energetically concentrate in seeking and interpretation of information (Nevid, 2009). Individual's intentionally impose, select or build environment to control their life events (Bandura, 2005). Theory claims four phases of humans' goal achievements, self-observation; individual's judgment towards target achievement and modification in individual's behavioral changes, self-evaluation; compare ones present functioning with desired working, self-reaction; individual's feedback on their performance and self-efficacy; ones beliefs to complete a particular task (Schunk \& Pajares, 2009; Zimmerman \& Cleary, 2009; van der Bijl \& Shortridge-Baggett, 2002). Important construct; self-efficacy has remained a deep-seated construct of social cognitive theory from last decades (Bandura, 2005, Barros, Laburú, \& Da Silva, 2010; Schunk \& Zimmerman, 2006; Zimmerman, 2008). Self-efficacy is the staple of all human behaviors that are influenced by individuals; mastery of experiences, vicarious experiences, social persuasion and physical states (Bandura, 1993; Goddard, Hoy, \& Hoy, 2000; Schunk \& Pajares, 2005; Zimmerman, 2008).

Self-efficacy; teachers' important cognitive attribute is pivotal inspirational construct which arouses students' curiosity towards learning. Teachers' self-efficacy has been remained measurable construct from last decades. It is considered as an indirect concept that provides equal support to research scholars for investigations (Banduara, 1997; Cakiroglu, 2008; Guskey \& Passaro, 1994). It significantly affects students' achievement scores (Mojavezi \& Tamiz, 2012; Mujis \& Rejnolds, 2001; Tournaki \& Podell, 2005). High efficacious teachers are confident on their skills, encourage students towards positive directions and concentrate on their educational achievements. They are more enthusiastic to solve students' educational problems by assigning different tasks (Allinder, 1994; Chacon, 2005; Mojavezi \& Tamiz, 2012; Podell \& Soodak, 1993). Efficacious teachers have more job opportunities and job securities as well (Pell, Iqbal, $\&$ Sohail, 2010; Shaukat, 2011). Researches show positive association between teachers' selfefficacy and students' achievement scores (Akhavan \& Tracz, 2016; Akinsola, 2008; Hoy; 2000; Mills, Pajares, \& Herron, 2007; Stevens, Harris, Aguirre-Munoz, Cobbs, 2009).

Categorically literature reports that teachers' self-efficacy directs students' confidence, controls students' educational declining level, overcomes learners' deficiencies and enhances students' learning approaches (Haung, Liu, \& Shiomi, 2007; Ho \& Hau, 2004). Plethora of studies reported that teachers' self-efficacy strongly effects on students' achievement scores (Adu, Tadu, \& Eze, 2012; Gulistan, Hussain, \& Mushtaq, 2017; Klassen \& Chiu, 2010; Rodríguez, Regueiro, Blas, Valle, Piñeiro, \& Cerezo, 2014; Ross, 1992; Shahzad \& Naureen, 2017; Yough, 2019).

Research conducted by Ross, (1992) explored the effect of teachers' self-efficacy on students' achievement scores. Findings report that students gained better marks that remained in contact with their teachers having better confidence on their abilities. Another research conducted by Pajares and Graham (1999) on a sample of 273 respondents confirms positive moderate association between teachers' self-efficacy and students' self-regulatory learning $\left(r=.53^{* *}, n=273, p<.01\right)$ and students' achievement scores $\left(r=.57^{* *}, n=273, p<.01\right)$. Another research was conducted by Motlagh, Amrai, Yazdani, Abderahim and Souri, (2011) in Tehran on the sample of 250 respondents. Self-constructed questionnaire was used after confirming Cronbach's Alpha reliability score, .79. Students' achievement scores were obtained from students. Researchers also confirmed normality of the data by using PourJafar Doust model (2010). Researchers analyzed data in SPSS using multiple regression and Pearson Correlation 
PROBLEMS

OF EDUCATION

IN THE $21^{\text {st }}$ CENTURY

Vol. 77, No. 5, 2019

Product Moment Correlation ( $r$ ). Results report that teachers' self-efficacy put significant effect on students' achievement scores. Findings of the research conducted by Tournaki and Podell (2005) on a sample of 384 teachers revealed that high efficacious teachers had fewer negative predictions towards students' achievement scores as compared to low efficacious teachers.

Pakistani social scientists conducted studies to measure the influence of teachers' selfefficacy on students' achievement scores. Research was conducted by Gulistan, Hussain and Mushtaq, (2017) on 576 respondents; 96 teachers and 480 students to investigate the impact of teachers' self-efficacy on students' achievement scores in Province Punjab. Data from teachers were collected through administering Tschannen-Moray and Hoy (2001) scale. Students' achievement scores were from concerned board of intermediate and secondary education. Findings confirmed strong positive association between teachers' efficacy beliefs and their students' achievement scores.

Shahzad and Naureen, (2017) find out association between teachers' self-efficacy and learners' scores on randomly selected sample of 160 respondents; 60 teachers and 100 students of Quetta applying Tschannen-Moran and Hoy (2001) long form scale. Results of the research depict significant association between teachers' self-efficacy and students' achievement scores $\left(r=.253^{* *}, n=100, p<.05\right)$, students' engagement and achievement scores $\left(r=.251^{* *}, n=100\right.$, $p<.05)$, teachers' self-efficacy and instructional strategies $\left(r=.249^{* *}, n=100, p<.05\right)$ and classroom management and students' achievement scores ( $\left.r=.249^{* *}, n=100, p<.05\right)$.

Language is a way of communication. It helps in cultural transformation and enlarges peoples' feelings. It is used as imparting instructions in educational institutions (Zaidi, 2010). Pakistan is a multilingual country and people speak Punjabi, Pashto, Sindhi, Sairaiki, Urdu, Balochi, Hindkoo and Barahavi in this region (Gopang, Panhwar, Chachar, \& Nizamani, 2016; Rahman, 2000). Punjabi, Sindhi, Pashto, Balochi and Saraiki are common communicative languages of Pakistan. Urdu is used as a national language (Lingua Franca) or a bridge among regional communication (Rahman, 2004). In Pakistani public sector educational institutions, to some extent Urdu and English are used as a mode of imparting instructions. Medium of instruction remains controversial in all levels of educational institutions since independence (Nisar \& Ahmad, 2011). This deep-rooted controversy was observed when English nation got hold and started governing in sub-continent (Rahman, 2000; Shamim, 2008). According to National Education Policy, (2009) bilingual dilemma is an important challenge for all level students. English is a global language and also pivotal for national development while Urdu produces national harmony within inhabitants of state. Mother tongue base instructions enhance students' conceptual understanding and build strong communication skills among students (Gopang et al., 2016). National Education Policy, (1998-2010) focuses that state departs students' secondary education and capability to express Urdu / English efficiently with strong communicative skills. Urdu language is made compulsory at a regional level and foreign language should be treated as the second priority so that students equally become proficient in both languages. According to researcher's view, mother tongue-based classroom instructions produce concepts on students' minds about topic. Teachers deliver lectures in indigenous language for the sake of students' concrete thoughts. It further confers that medium of education at all levels shall be a regional language.

Teachers' self-efficacy is considered as a key construct which affects students' achievement scores in controversial medium of education perspectives (Shamim, 2008). Teachers maximize their abilities inserting more effort during classroom teaching and provide factual information among students. But students remain deprived and achieve fewer scores in exams. Public sector secondary school education is going to be turning down gradually and students show poor scores (Adu, Tadu, \& Eze, 2012). This declining level of student poor achievement score is due to teachers' slackness (Kitti, 2014). 
PROBLEMS

OF EDUCATION

IN THE $21^{\text {st }}$ CENTURY

Vol. 77 , No. 5, 2019

670

\section{Research Problem}

Pakistani male and female secondary school teachers are providing their cognitive and pedagogical services in public and private schools to enhance students' achievement scores. It is a common observation that single medium of education makes students' learning strong and effective. Literature reported that Pakistani students remain common users of multiple languages at their different age levels in educational institutions (Gopang et al., 2016; Government of Pakistan, 2006a, 2007, 2009, 2010; Rahman, 2004; Shamim, 2008). Resultantly they make poor progress and obtain less marks in this regard. Researchers tried to explore the effect of selfefficacy on teachers' gender, age, qualification, teaching experience with students' achievement scores. But none of the research was focused to explore the effect of teachers' self-efficacy on students' achievement scores in controversial educational perspective in Pakistani context. Research is eager to find out actual situations of teachers' slackness happening in controversial medium of instruction perspectives. Researchers want to explore the effect of teachers' selfefficacy on students' achievement scores in multilingual medium of education perspective in educational landscape of Punjab Province.

\section{Research Methodology}

\section{General Background}

Present research was conducted to measure the effect of teachers' self-efficacy in terms of English and Urdu medium of educational perspectives on secondary school students' achievement scores. Research was quantitative in nature and applying causal-comparative design that investigates cause and effect between already existed dependent and independent variables (Field, 2009; Fraenkel, Wallen, \& Hayun, 2012; Gay, Mills, Airasian, 2006; Lodico, Spaulding, \& Voegtle, 2006).

\section{Population and Sample Selection}

Male secondary school teachers and students working in public sector secondary schools comprised the population of research. Currently there are working 1993 secondary school teachers and 73584 students in District Kasur, of Punjab Province (Government of Punjab, 2015; Punjab Development Statistics, 2015). Sample of the research consisted of conveniently selected 1100 respondents: 300 teachers and 800 students of $10^{\text {th }}$ grade, from male public sector secondary schools of Kasur. It was difficult for the researchers to collect data from female teachers as they are less cooperative and not easily provide data. It is appropriate to select 10-30 \% representative sample of the research (Connelly, 2008; Hertzog, 2008; Hill, 1998; Johanson \& Brooks, 2010; Julious, 2005; Van Belle, 2011).

\section{Data Collection Instrumentation and Procedures}

Data collection is one of the important phases that direct researchers towards ending research process administering self-constructed / standardized instrument. Research collected data from teachers by administering standardized long form Tschannen-Moran and Hoy (2001) long form self-efficacy scale; known as Ohio State Teachers' Efficacy Scale (Senler \& SungurVural, 2013). Researcher sought unfettered and unrestricted permission from authors upon request for scale usage. Scale is categorized in 24 items consisting of three parts; efficacy in students' engagement 8 items, efficacy in instructional strategies 8 items and efficacy in classroom management comprised of 8 items mode of 5-point Likert type options. Due to 
cultural issues and time constrains, it was less possible for the researcher to get an easy access on female teachers working in Pakistani educational institutions of District Kasur. Females make poor cooperation and feel shy to provide accurate data used for the research purpose. Research was delimited to public sector male secondary schools as they are following national curricula as per Government instructions. Data were collected by researcher himself focusing ethical considerations. Researcher assured participants' informed consent, confidentiality, anonymity and risk of harm both physical and psychological as the result of their volunteer participation for data collection from respondents (Beebe \& Smith, 2008; Bhutta, 2004; DeCosta, D'Souza, Krishnan, Chhabra, Shihaam \& Goswami, 2004; Jegede, 2009; Bull \& Lindegger, 2011; Kass, Maman \& Atkinson, 2005; Lo, 2012; Marshall, 2007). Collected data were entered in SPSS to confirm overall Cronbach's Alpha reliability statistics scores .851 whereas factor wise reliability of instrument is given below:

Table 1. Reliability statistics.

\begin{tabular}{llll}
\hline No & Factors' name & Cronbach's Alpha & No. of items \\
\hline 1 & Students' engagement & .854 & 8 \\
\hline 2 & Instructional strategies & .847 & 8 \\
\hline 3 & Classroom management & .851 & 8 \\
\hline
\end{tabular}

Academic achievement results of $9^{\text {th }}$ grade students were obtained from Board of Intermediate and Secondary Education gazette Lahore after ensuring students' enrollment during data collection. Normality of the data was confirmed by calculating Shapiro-Wilk's test in SPSS, $p>.05, n<2000$. Normal distributed data are considered as more trendy, easy to exercise, provide excellent estimation, grant perfect direction towards application of parametric and non-parametric test, easy to analyze and interpret for smooth results (Elliott \& Woodward, 2007; Öztuna, Elhan, \& Tüccar, 2006; Senler \& Sungur-Vural, 2013; Thode, 2002). Literature reported that Shapiro-Wilk's test having value, $p>.05, n<2000$ and Kolmogrov-Smirnov test, $p>.05, n<2000$ are appropriate tests that confirm normality of data (Elliott \& Woodward, 2007; Field, 2009; Peat \& Barton, 2008; Singh, Masuku, 2014).

\section{Table 2. Tests of normality.}

\begin{tabular}{llllllll}
\hline \multirow{2}{*}{ No. } & \multirow{2}{*}{ Names of variables } & \multicolumn{7}{l}{ Kolmogorov-Smirnov ${ }^{\mathbf{a}}$} & \multicolumn{3}{l}{ Shapiro-Wilks } \\
& & K-S & $d f$ & $p$ & $S-W$ & df & $p$ \\
\hline 1 & Medium of education & .430 & 300 & .01 & .591 & 300 & .361 \\
2 & Teachers' self-efficacy & .186 & 300 & .01 & .891 & 300 & .084 \\
3 & Students' achievement scores & .083 & 300 & .01 & .976 & 300 & .156 \\
4 & Students' engagement & .186 & 300 & .01 & .883 & 300 & .231 \\
5 & Educational strategies & .166 & 300 & .01 & .893 & 300 & .681 \\
6 & Classroom management & .196 & 300 & .01 & .889 & 300 & .912 \\
a. Significance Correction & & & & & & \\
\hline
\end{tabular}

\section{Data Analysis}

Following section improvised analysis of data collected from secondary school teachers and students. There were 24 Likert type statements. Data were analyzed applying regression analysis techniques. Techniques were applied to explore the effect of teachers' self-efficacy in bilingual medium of education perspectives on students' achievement scores.

\begin{tabular}{l} 
PROBLEMS \\
OF EDUCATION \\
IN THE 21 $1^{\text {st }}$ CENTURY \\
Vol. 77, No. 5, 2019 \\
\hline 671
\end{tabular}


PROBLEMS

OF EDUCATION IN THE $21^{\text {st }}$ CENTURY Vol. 77, No. 5, 2019

672

\section{Research Results}

Data were entered in SPSS version 16 for smooth analysis. Researchers applied simple and multiple regression analysis techniques to explore the effect of self-efficacy on students' achievement scores. Results and interpretation are shown in the following tables:

Table 3. Effect of teachers' self-efficacy on students' achievement scores.

\begin{tabular}{lllllll}
\hline No & Model & $\boldsymbol{B}$ & $\boldsymbol{S E}$ & $\boldsymbol{\beta}$ & $\boldsymbol{t}$ & $\boldsymbol{p}$ \\
\hline \multirow{2}{*}{1} & (Constant) & -4.220 & 14.225 & & -.297 & .767 \\
& Teachers' self-efficacy & 1.849 & .078 & .808 & 23.753 & .001 \\
\hline Note: & $R=.808^{\text {a }}, R^{2}=.654 ; F=(1,299)=564.211, p<.05^{\text {a }}$ & & & &
\end{tabular}

Table 3 depicts construction of significant regression equation $(F(1,299)=564.211$, $p<.01$ having .654 value of $\mathrm{R}^{2}$ with $65.40 \%$ explained variations were observed with standardized regression coefficient $(\beta=.808)$. Showing results of regression coefficient, interpretation of independent sample t-test portrays that teachers' efficacy put important effect on students' achievement scores, $t(198)=23.753, p<.01$. Students' achievements were equal to $-4.220+1.849$ scores where teachers' self-efficacy was gauged by using their self-confidence during classroom activities. It is concluded that students' achievements were raised to 1.849 scores by applying teachers' self-efficacy on students to acquire their better achievement scores.

Table 4. Effect of teachers' self-efficacy in sub-scales of students' engagement, instructional strategies and classroom management on students' achievement scores.

\begin{tabular}{llllllllll}
\hline No & Model & $\boldsymbol{F}$ & $\boldsymbol{R}$ & $\boldsymbol{R}^{2}$ & $\boldsymbol{B}$ & $\boldsymbol{S E}$ & $\boldsymbol{\beta}$ & $\boldsymbol{t}$ & $\boldsymbol{p}$ \\
\hline & (Constant) & & & & -9.981 & 15.714 & & -.635 & .526 \\
1 & Students' engagement & 427.888 & $.767^{\mathrm{a}}$ & .589 & 2.128 & .506 & .308 & 4.209 & .001 \\
2 & Instructional strategies & 456.371 & $.777^{\mathrm{a}}$ & .604 & 1.384 & .541 & .230 & 2.558 & .011 \\
3 & Classroom management & 435.599 & $.770^{\mathrm{a}}$ & .593 & 2.116 & .519 & .311 & 4.081 & .001 \\
\hline Note: & $R=.809^{\mathrm{a}}, R^{2}=.655, \beta=.283 ; F=(3,297)=439.952, p<.05^{\mathrm{a}}$
\end{tabular}

Table 4 reflects that linear regression was applied to explore the effect of teachers' self-efficacy on students' achievement scores. Interpretation report formation of significant regression equation $\left(F(1,299)=439.952, p<.01\right.$ having .655 value of $\mathrm{R}^{2}$ with $65.55 \%$ increased variance were observed with construction of standardized regression equation $(\beta=.283)$. Results also depict positive effect on students' engagement with construction of significant regression equation $(F(1,299)=427.888, p<.01)$ having .589 value of $R^{2}$ with $58.90 \%$ increased variances were seen with standardized regression coefficient $(\beta=.308)$, instructional strategies, $\left(F(1,299)=456.371, p<.01\right.$ having .604 value of $R^{2}$ with $60.4 \%$ increased variance were observed with standardized regression coefficient $(\beta=.230)$ and classroom management, $(\mathrm{F}(1$, $299)=435.599, p<.01)$ having .593 value of $\mathrm{R}^{2}$ with $59.3 \%$ increased variance were observed with formation of standardized regression coefficient $(\beta=.311)$. Reporting output of regression coefficient, the results of independent sample t-test depict that teachers' self-efficacy in terms of students' engagement, $t(198)=4.209, p<.01$, instructional strategies, $t(198)=2.558, p<.05$ and classroom management strategies, $t(198)=4.081, p<.01$ was a significant predictor on students' achievement scores. Students estimated achievements were equal to $-9.981+2.128+1.384+2.116$ 
scores where teachers' self-efficacy was gauged through applying their students' engagement, instructional and classroom management potential applied during classroom teaching learning process. It is concluded that students' achievement was raised to 5.628 scores by exerting teachers' self-efficacy in classroom for students' better achievement scores.

Table 5. Effect of teachers' medium of education on students' achievement scores.

\begin{tabular}{lllllll}
\hline No. & Model & $\boldsymbol{B}$ & $\boldsymbol{S E}$ & $\boldsymbol{\beta}$ & $\boldsymbol{t}$ & $\boldsymbol{p}$ \\
\hline \multirow{2}{*}{1} & Students' achievement scores & 184.762 & 13.175 & & 14.024 & .01 \\
& Medium of education & 85.789 & 7.577 & .548 & 11.322 & .01 \\
\hline
\end{tabular}

Note: $\quad R=.548^{\mathrm{a}}, R^{2}=.300 ; F=(1,299)=128.184, p<.05^{\text {a }}$

Table 5 confirms structuring of significant linear regression equation $(F(1,299)=128.184$, $p<.01$ ) having .300 value of $R^{2}$ with $30 \%$ increased variance with formation of standardized regression coefficient $(\beta=.548)$. Reporting results of regression coefficient, output of independent sample t-test claim that teachers' medium of education was a significant predictor on students' achievement scores, $t(198)=11.322, p<.01$. Students' estimated achievement was equal to $184.762+85.789$ scores where self-efficacy in account of teachers' medium of education was measured through teachers' imparting instructions in Urdu and English during classroom based on their confidence. It is concluded that students' achievement scores were raised to 85.789 by exerting teachers' medium of education on students' better achievement scores.

\section{Discussion}

Self-efficacy is teachers' pivotal cognitive attribute used to achieve students' particular tasks. Focusing the worth of measureable construct; self-efficacy, present research was carried out to explore the influence of teachers' self-efficacy on students' achievement scores in multilingual in medium of education perspectives. Researchers make significant contributions in this regard. Mojavezi and Tamiz (2012) investigated the effect of teachers' self-efficacy on students' achievement scores on a sample of 230 respondents; 80 teachers and 150 students in Iran. Researchers administered Tschannen-Moran and Hoy (2001) scale to collect data from teachers. Data was analyzed in SPSS calculating Pearson correlation $(r)$ and one-way ANOVA. Findings showed strong association between teachers' self-efficacy and students' achievement scores. Results of the research shows also significant effect of teachers' self-efficacy on students' achievement scores $(F(1,299)=564.211, p<.01)$. Results of current research support the findings of Mojavezi and Tamiz, (2012). Research was conducted by Wolters and Daugherty, (2007) with the respondents of 1130 teachers and 1024 students selected from suburban district of Texas state. Researchers collected data by self-report survey via internet administering Tschannen-Moran and Hoy (2001) long scale comprised of 24 statement mode of 5-point Likert type options. Teachers' age, qualification, teaching subject, teaching experience were also taken into consideration. Findings show that teachers' self-efficacy put significant effect on students' qualification $(F(6,2020)=11.23, p<.05)$, teachers' teaching experience, $(F(9,2458)=8.27$, $p<.01)$ and found no significant effect of teaching subjects on students' achievement scores, $(F(18,2857)=1.58, p>.05)$. Findings of present research support and claim effect of teachers' medium of education $(F(1,299)=128.184, p<.01)$, nature of employment, age, and professional qualification, teaching experience and teaching subjects on students' achievement scores.

\begin{tabular}{l} 
PROBLEMS \\
OF EDUCATION \\
IN THE 21 2 st CENTURY \\
Vol. 77, No. 5, 2019 \\
\hline 673
\end{tabular} 
PROBLEMS

OF EDUCATION IN THE $21^{\text {st }}$ CENTURY Vol. 77, No. 5, 2019

674

Results of current research support the findings of Wolters and Daugherty, (2007). Adu, Tdu and Eze, (2012) conducted a research to correlate teachers' self-efficacy with students' achievement scores in four Nigerian states. Researchers employed descriptive survey adopting ex-post-facto research design on sample of 6712 respondents; 1612 secondary school teachers and 5100 students using multistage sampling technique. Output of Pearson Product Moment Correlation (r) and regression analysis techniques showed positive significant relationship between teachers' self-efficacy and students' achievement scores $\left(r=.38^{* *}, n=6712, p<.05\right)$. Findings support the findings of current research $(F(1,299)=564.211, p<.01)$ and also the findings of other studies (Allinder, 1995; Goddard, 2002; Adediwura \& Toyu, 2007). Results show that 65.4 $\%$ teachers' self-efficacy effect on students' achievement scores with formation of significant regression equation $(F(1,299)=564.211, p<.01)$ and support the findings of Tai, Hu, Wang and Chen (2012) which claims that $47.8 \%$ self-efficacy effects on teachers' satisfaction towards learning and teachers' self-efficacy $72 \%$ effect on students' achievement scores. Current research support that $65.4 \%$ teachers' self-efficacy effect on students' achievement scores with formation of regression equation $(F(1,299)=564.211, p<.01)$. Research conducted by Shaukat and Iqbal, (2012) on a sample of 198 teachers administering Moran and Hoy, (2001) scale comprised of 24 Likert type items. Research was quantitative in nature, independent sample t-test and ANOVA were applied. Results depict that self-efficacy effect on teachers' professional qualification, nature of job and age that contradict with the results of the research and support the findings of the research conducted by Gulistan, Hussain and Mushtaq, (2017) that report that teachers' self-efficacy uncertainly affect students' achievement scores. Present research shows strong positive effect of teachers' medium of instruction on students' achievement scores $(F(1,299)=128.184, p<.01)$.

\section{Conclusions}

Self-efficacy is an important cognitive attribute that has strong effect to accomplish goal achievements. Teachers' self-efficacy refers to teachers' attribute used in classroom for the sake of students' better achievement scores. Current research was conducted to explore the effect of teachers' self-efficacy on secondary school students' achievement scores in medium of instruction perspective. Pakistani secondary school teachers' workings in public sector secondary schools of Punjab are trying their best towards students' educational success. Present research concludes that Pakistani public sector male secondary school teachers' selfefficacy has strong effect on students' achievement scores. Research shows that teachers invest their maximum potential among students focusing their educational and pedagogical confidence for the sake of students' better achievement scores. Present research concludes that Pakistani secondary school teachers $34.6 \%$ were lack in their self-efficacy whereas students' engagement 41.1 , instructional strategies $39.6 \%$ and $40.7 \%$ were less applying their classroom management potential among students. Higher qualified teachers are more efficacious towards students' achievements. Research concludes that teachers' medium of instruction $70 \%$ effects on students' achievement scores although medium of education remained controversial since independence. Teachers' impart instruction in diverse medium of education perspectives; Urdu, English and mother language as well. Students' feel confusion and cannot understand basic concept clearly. There is lack of misunderstanding and misconception among students' cognitive level. Teachers' impart instructions whole heartedly but medium of imparting instruction is a major obstacle in this regards that de-motivate students towards success. Resultantly students less understand lectures properly. They remain deprived and cannot obtain good achievement scores due to controversial medium on education. 
Present research strongly recommends that it is a dire need for Government to take revolutionary steps for public sector secondary schools' teachers to enhance their self-efficacy by providing them training, conducting seminars and conferences. Trainers, motivators and school heads need to play significant role to maximize teachers' academic and professional confidence on their abilities at teachers' work place. Focusing the scenario of international standards, Government may implement single medium of education; English / Urdu in public sector secondary schools of Punjab as bilingual medium of education is one of the cause that lead students towards poor achievements.

\section{Acknowledgements}

Author is very thankful to Prof. Dr. Rafaqat Ali Akbar, Director, Institute of Education and Research, Punjab University, Lahore for his encouragement and professional support during completion of research article. It was only because of his inspiring guidance and dynamic supervision that present research article could be prepared.

\section{References}

Adeyemo, D. A. (2005). Parental involvement interest in schooling and school environment as predictors of self-efficacy among fresh secondary school student in Oyo State, Nigeria. Electronic Journal of Research in Educational Psychology, 5(1), 163-180.

Adediwura, A. A., \& Tayo, B. (2007). Perception of teachers' knowledge, attitude and teaching skills as predictor of performance in Nigerian secondary schools. Educational Research and Reviews, 2(7), 165-171.

Adu, E. O., Tadu, R., \& Eze, I. (2012). Teachers' self-efficacy as correlates of secondary school students' achievement in southwestern Nigeria. Discovery, 2(4), 8-16.

Akhavan, N., \& Tracz, S. (2016). The effects of coaching on teacher efficacy, academic optimism and student achievement: The consideration of a continued professional development option for teachers. Journal of Education and Human Development, 5(3), 38-53. https://doi.org/10.15640/ jehd.v5n3a5.

Akinsola, M. K. (2002). In-service elementary teachers' mathematics anxiety and its relationship to teachers' attitude towards the researching and teaching of mathematics. Nigerian Journal of Applied Psychology, 7, 188-202. doi:10.12691/education-2-12A-7.

Akinsola, M. K. (2008). Relationship of some psychological variables in predicting problem solving ability of in-service mathematics teachers. The Montana Mathematics Enthusiast, 5(1), 79-100.

Allinder, R. M. (1994). The relationship between efficacy and the instructional practices of special education teachers and consultants. Teacher Education and Special Education, 17, 86-95. doi: $10.1177 / 088840649401700203$.

Allinder, R. M. (1995). An examination of the relationship between teacher efficacy and curriculumbased measurement and student achievement. Remedial and Special Education, 16, 247-254. doi: $10.1177 / 074193259501600408$.

Axtell, C. M., \& Parker, S. K. (2003). Promoting role breadth self-efficacy through involvement, work redesign and training. Human Relations, 56, 113-131. doi:10.1177/0018726703056001452.

Bandura, A. (1993). Perceived self-efficacy in cognitive development and functioning. Educational Psychologist, 28, 117-148. doi:10.1207/s15326985ep2802_3.

Bandura, A. (1997). Self-Efficacy: The exercise of control. New York: W. H. Freeman and Company.

Bandura, A. (1977). Self-efficacy: Toward a unifying theory of behavioral change. Psychological Review, 84, 191-215. doi:10.1016/0146-6402(78)90002-4.

Bandura, A. (2002). Social cognitive theory in cultural context. Applied Psychology: An International Review, 51, 269-290. doi:10.1111/1464-0597.00092.

Bandura, A. (2005). The evolution of social cognitive theory. In K. G. Smith \& M. A. Hitt (Eds.), Great minds in management (p.1) Oxford: Oxford University Press. 
PROBLEMS

OF EDUCATION IN THE $21^{\text {st }}$ CENTURY Vol. 77, No. 5, 2019

676

Barros, M. A., Laburú, C. E., \& Da Silva, F. R. (2010). An instrument for measuring self-efficacy beliefs of secondary school Physics teachers. Procedia-Social and Behavioral Sciences, 2, 3129-3133. doi:0.1016/j.sbspro.2010.03.476.

Beebe, L. H., \& Smith, K. (2008). Examining informed consent in persons with schizophrenia. Issues in Mental Health Nursing, 29(4), 397-410.

Bhutta, Z. A. (2004). Beyond informed consent. Bulletin of the World Health Organization, 82(10), 771777.

Bull, S., \& Lindegger, G. C. (2011). Ensuring consent to research is voluntary: How far do we need to go? The American Journal of Bioethics, 11(8), 27-29.

Cakiroglu, E. (2008). The teaching efficacy beliefs of pre-service teachers in the USA and Turkey. Journal of Education for Teaching, 34, 33-44. doi:10.1080/02607470701773457.

Chacon, C. T. (2005). Teachers' perceived efficacy among English as a foreign language teachers in middle schools in Venezuela. Teaching and Teacher Education, 21, 257-272. doi:10.1016/j. tate.2005.01.001.

Connelly, L. M. (2008). Pilot studies. Medsurg Nursing, 17(6), 411-413.

Crothers, L. M., Hughes, T. L., \& Morine, K. A. (2011). Theory and cases in school-based consultation: A resource for school psychologists, school counselors, special educators, and other mental health professionals ( $\left.1^{\text {st }} \mathrm{ed}.\right)$. London, NY; Routledge.

Cunningham, B. A. (2003). A research of the relationship between school culture and student achievement. Published Doctoral Dissertation, University of Central Florida, USA.

DeCosta, A., D'souza, N., Krishnan, S., Chhabra, M. S., Shihaam, I., \& Goswami, K. (2004). Community based trials and informed consent in rural north India. Journal of Medical Ethics, 30(3), 318-323.

Duncan, T. G., \& McKeachie, W. J. (2005). The making of the motivated strategies for learning questionnaire. Educational Psychologist, 40, 117-128. doi:10.1207/s15326985ep4002_6.

Elliott, A. C., \& Woodward, W. A. (2007). Statistical analysis quick reference guidebook: With SPSS examples ( $\left.1^{\text {st }} \mathrm{ed}\right)$. London: Sage.

Field, A. (2009). Discovering statistics using SPSS (3 ${ }^{\text {rd }}$ ed.). London, NY; Sage.

Fraenkel, J. R., Wallen, N. E., \& Hayun, H. H. (2012). How to design and evaluate research in education $\left(8^{\text {th }}\right.$ ed. $)$. New York: McGraw-Hills.

Gay, L. R., Mills, G. E., \& Airasian, P. (2006). Education research: Competencies for analysis and applications. Columbus, $\mathrm{OH}$ : Pearson Education.

Goddard, R. D., Hoy, W. K., \& Hoy, A. W. (2000). Collective teacher efficacy: Its meaning, measure, and impact on students' achievement. American Educational Research Journal, 37, 479-507. doi: $10.3102 / 00028312037002479$.

Goddard, R. (2002). A theoretical and empirical analysis of the measurement of collective efficacy: The development of a short form. Educational and Psychological Measurement, 62, 97-110. doi:10.1 177/0013164402062001007.

Gopang, A. S., Panhwar, A. H., Chachar, A. A., \& Nizamani, H. A. (2016). Issue of language as the medium of instruction in Pakistan: An analytical research. The Shield-Research Journal of Physical Education \& Sports Science, 11, 91-106.

Government of Pakistan. (1998). Education Policy 1998-2010. Islamabad: Ministry of Education.

Government of Pakistan. (2006 a). Green paper on national education policy review process: Textbook and learning materials. Islamabad: Policy and Planning Wing, Ministry of Education.

Government of Pakistan. (2007). National textbook and learning materials policy and plan of action. Islamabad: Curriculum Wing, Ministry of Education.

Government of Pakistan. (2009). National education policy 2009. Islamabad: Ministry of Education.

Government of Pakistan. (2010). A Manual for Curriculum Development 2010. Curriculum Wing, Islamabad: Ministry of Education.

Government of Punjab. (2015). Punjab Development Statistics. Lahore, Pakistan: Bureau of Statistics.

Gulistan, M., Hussain, M. A., \& Mushtaq, M. (2017). Relationship between mathematics teachers' selfefficacy and students' achievement at secondary level. Bulletin of Education and Research, 39(3), 171-182.

Guskey, T. R. (1987). Context variables that affect measures of teacher efficacy. The Journal of Educational Research, 81, 41-47. doi:10.1080/ 00220671.1987. 10885795.

Guskey, T. R., \& Passaro, P. D. (1994). Teacher efficacy: A study of construct dimensions. American Educational Research Journal, 31, 627-643. doi:10.3102/00028312031003627. 
Hertzog, M. A. (2008). Considerations in determining sample size for pilot studies. Research in Nursing \& Health, 31, 180-191. doi:10.1002/nur.20247.

Hill, R. (1998). What sample size is "enough" in internet survey research. Interpersonal Computing and Technology: An Electronic Journal for the 21 $1^{\text {st }}$ Century, 6(3), 1-12.

Ho, I. T., \& Hau, K. T. (2004). Australian and Chinese teacher efficacy: Similarities and differences in personal instruction, discipline, guidance efficacy and beliefs in external determinants. Teaching and Teacher Education, 20, 313-323. doi:10.1016/j.tate.2003.09.009.

Hoy, A. W. (2000-April). Changes in teacher efficacy during the early years of teaching. Paper presented at the annual meeting of the American educational research association, New Orleans, LA.

Jegede, A. S. (2009). Understanding informed consent for participation in international health research. Developing World Bioethics, 9(2), 81-87.

Johanson, G. A., \& Brooks, G. P. (2010). Initial scale development: Sample size for pilot studies. Educational and Psychological Measurement, 70, 394-400. doi:10.1177/0013164409355692.

Julious, S. A. (2005). Sample size of 12 per group rule of thumb for a pilot research. Pharmaceutical Statistics, 4, 287-291. doi:10.1002/pst.185.

Kass, N. E., Maman, S., \& Atkinson, J. (2005). Motivations, understanding, and voluntariness in international randomized trials. IRB: Ethics and Human Research, 27(6), 1-8.

Klassen, R. M., \& Chiu, M. M. (2010). Effects on teachers' self-efficacy and job satisfaction: Teacher gender, years of experience, and job stress. Journal of Educational Psychology, 102, 741-756. doi:10.1037/a0019237.

Kitti, M. R. (2014). Effect of Teaching Methods on Students' Performance in Tanzanian Education Institutions: A Case of Public Secondary Schools in Nyamagana District-Mwanza, Published Doctoral dissertation, The Open University of Tanzania.

Lo, B. (2012). Ethical Issues in clinical research: A practical guide (1 ${ }^{\text {st }}$ ed.). San Francisco, USA; Lippincott Williams \& Wilkins.

Lodico, M., Spaulding, D., \& Voegtle, K. (2006). Methods in educational research: From theory to practice. San Francisco: Jossey-Bass.

Marshall, P. L. (2007). Ethical challenges in research design and informed consent for health research in resource-poor settings (Vol. 5). World Health Organization.

Mclnerney, D. M. (2005). Educational psychology-theory, research, and teaching: A 25-year retrospective. Educational Psychology, 25, 585-599. doi:10.1080/01443410500344670.

Mills, N., Pajares, F., \& Herron, C. (2007). Self-efficacy of college intermediate French students: Relation to achievement and motivation. Language learning, 57, 417-442. doi:10.1111/j.14679922.2007.00421.x.

Mojavezi, A., \& Tamiz, M. P. (2012). The impact of teacher self-efficacy on the students' motivation and achievement. Theory and Practice in Language Studies, 2, 483-491. doi:10.4304/tpls.2.3.483491.

Montigny, F., \& Lacharité, C. (2005). Perceived parental efficacy: Concept analysis. Journal of Advanced Nursing, 49, 387-396. doi:10.1111/j.1365-2648.2004. 03302.x.

Motlagh, S. E., Amrai, K., Yazdani, M. J., Abderahim, H. A., \& Souri, H. (2011). The relationship between self-efficacy and achievement in high school students. Procedia-Social and Behavioral Sciences, 15, 765-768.

Muijs, R. D., \& Rejnolds, D. (2001). Teachers' beliefs and behaviors: What really matters. Journal of Classroom Interaction, 37, 3-15.

Mulholland, J., \& Wallace, J. (2001). Teacher induction and elementary science teaching: Enhancing selfefficacy. Teaching and Teacher Education, 17, 243-261. doi:10.1016/S0742-051X(00)00054-8.

Nevid, J. S. (2009). Psychology: Concepts and applications (3 ${ }^{\text {rd }}$ ed.). Boston: Houghton Mifflin Company.

Nisar, A., \& Ahmad, S. I. (2011). Performance of Secondary School Certificate (SSC) graduates of English and Urdu medium schools: A comparative research. Language in India, 11(4), 201-205.

Öztuna, D., Elhan, A., \& Tüccar, E. (2006). Investigation of four different normality tests in terms of type 1 error rate and power under different distributions. Turkish Journal of Medical Sciences, 36(3), $171-176$.

Pajares, F., \& Graham, L. (1999). Self-efficacy, motivation constructs, and mathematics performance of entering middle school students. Contemporary Educational Psychology, 24, 124-139. doi:10.1006/ceps.1998.0991. 
PROBLEMS

OF EDUCATION IN THE $21^{\text {st }}$ CENTURY Vol. 77 , No. 5, 2019

678

Peat, J., \& Barton, B. (2008). Medical statistics: A guide to data analysis and critical Appraisal ( $1^{\text {st }}$ ed.). New Jersey: John Wiley \& Sons.

Pell, A. W., Iqbal, H. M., \& Sohail, S. (2010). Introducing science experiments into rote learning classes in Pakistani middle school classrooms. Evaluation and Research in Education, 23, 191-212. doi: 10.1080/09500790.2010.489151.

Pintrich, P. R., \& Schunk, D. H. (2002). Motivation in education: Theory, research, and applications $\left(2^{\text {nd }}\right.$ ed.). Upper Saddle River, NJ: Prentice Hall.

Podell, D. M., \& Soodak, L. C. (1993). Teacher efficacy and bias in special education referrals. The Journal of Educational Research, 86, 247-253. doi:10.1080/00220671.1993.9941836.

Pourjafar Doust, Camellia. (2010). Construction and standardization of students self-efficacy test. Karaj, Allameh Tabataba'i University, Tehran.

Punjab Development Statistics. (2015). Bureau of statistics, Government of the Punjab. Lahore: Pakistan.

Rahman, T. (2000). The language of employment: The case of Pakistan. Journal of South Asian and Middle Eastern Studies, 23(4), 1-18.

Rahman, T. (2004). Denizens of alien worlds: A survey of students and teachers at Pakistan's Urdu and English language-medium schools, and madrassas. Contemporary South Asia, 13, 307-326. doi:1 $0.1080 / 0958493042000272212$.

Rodríguez, S., Regueiro, B,. Blas, R., Valle, A., Piñeiro, I., \& Cerezo., R. (2014). Teacher self-efficacy and its relationship with students' affective and motivational variables in higher education. European Journal of Education and Psychology, 7, 107-120 doi:org/10.1989/ejep.v7i2.183.

Ross, J. A. (1992). Teacher efficacy and the effects of coaching on student achievement. Canadian Journal of Education, 17, 51-65. doi:10.2307/1495395.

Schunk, D. H., \& Pajares, F. (2005). Competence perceptions and functioning. In A. J. Elliot, \& C. S. Dweck (Eds.), Handbook of competence and motivation (pp. 85-104). New York, NY: Guilford Press.

Schunk, D. H., \& Pajares, F. (2009). Self-effi cacy theory. In K. R. Wentzel \& A. Wigfield (Eds.) Handbook of motivation in school (pp. 35-54). New York: Taylor Francis.

Schunk, D. H., \& Zimmerman, B. J. (2006). Competence and control beliefs: Distinguishing the means and ends. In P. A. Alexander \& P. H. Winne (Eds.). Handbook of educational psychology (pp. 349367). Mahwah, NJ: Lawrence Erlbaum.

Senler, B., \& Sungur-Vural, S. (2013). Pre-service science teachers' teaching self-efficacy in relation to personality traits and self-regulation. The Spanish Journal of Psychology, 16, 1-20. doi:10.1017/ sjp.2013.22.

Shahzad, K., \& Naureen, S. (2017). Impact of teacher self-efficacy on secondary school students' achievement. Journal of Education and Educational Development, 4, 48-72. doi:10.22555/joeed. v4i1.1050.

Shamim, F. (2008). Trends, issues and challenges in English language education in Pakistan. Asia Pacific Journal of Education, 28, 235-249. doi:10.1080/0218879080226 7324.

Shaukat, S. (2011). Development and validation of in-service teachers' self-efficacy beliefs in the context of Pakistan. Evaluation \& Research in Education, 24, 121-141. doi:10.1080/09500790.2011.55 6249.

Shaukat, S., \& Iqbal, H. M. (2012). Teacher self-efficacy as a function of student engagement, instructional strategies and classroom management. Pakistan Journal of Social and Clinical Psychology, 9(3), 82-86.

Singh, A. S., \& Masuku, M. B. (2014). Normality and data transformation for applied statistical analysis. International Journal of Economics, Commerce and Management, 2(7), 1-11.

Smylie, M. A. (1988). The enhancement function of staff development: Organizational and psychological antecedents to individual teacher change. American Educational Research Journal, 25, 1-30. doi: $10.3102 / 00028312025001001$.

Smylie, M. A., Lazarus, V., \& Brownlee-Conyers, J. (1996). Instructional outcomes of school-based participative decision making. Educational Evaluation and Policy Analysis, 18, 181-198. doi:0.3102/01623737018003181.

Stevens, T., Harris, G., Aguirre-Munoz, Z., \& Cobbs, L. (2009). A case research approach to increasing teachers' mathematics knowledge for teaching and strategies for building students' maths selfefficacy. International Journal of Mathematical Education in Science and Technology, 40, 903914. doi:10.1080/00207390903199269. 
Tai, D. W. S., Hu, Y. C., Wang, R., \& Chen, J. L. (2012, February). What is the Impact of Teacher SelfEfficacy on the Student Learning Outcome? For paper presented at $3^{\text {rd }}$ WIETE Annual Conference on Engineering and Technology Education Pattaya, Thailand.

Thode, H. J. (2002). Testing for normality. New York: Marcel Dekker.

Tournaki, N., \& Podell, D. M. (2005). The impact of student characteristics and teacher efficacy on teachers' predictions of student success. Teaching and Teacher Education, 21, 299-314. doi:10.1016/j.tate.2005.01.003.

Tschannen-Moran, M., Hoy, A. W, \& Hoy, W. K. (1998). Teacher efficacy: Its meaning and measure. Review of Educational Research, 68, 202-248. doi:10.3102/00346543068002202.

Tschannen-Moran, M., \& Hoy, A. W. (2001). Teacher efficacy: Capturing an elusive construct. Teaching and Teacher Education, 17, 783-805. doi:10.1016/S0742-051X(01)00036-1.

Tschannen-Moran, M., \& Hoy, A. W. (2007). The differential antecedents of self-efficacy beliefs of novice and experienced teachers. Teaching and Teacher Education, 23, 944-956. doi:10.1016/j. tate.2006.05.003.

Tschannen-Moran, M., Hoy, A. W., \& Hoy, W. K. (1998). Teacher efficacy: Its meaning and measure. Review of Educational Research, 68, 202-248. doi:10.3102/00346543068002202.

Van Belle, G. (2011). Statistical rules of thumb (Vol. 699). New York: John Wiley \& Sons.

van der Bijl, J., \& Shortridge-Baggett, L. M. M. (2002). The theory and measurement of the self-efficacy construct. Self-efficacy in Nursing: Research and Theory for Nursing Practice, 15(3), 189-207.

Wolters, C. A., \& Daugherty, S. G. (2007). Goal structures and teachers' sense of efficacy: Their relation and association to teaching experience and level. Journal of Educational Psychology, 99, 181193. doi:10.1037/0022-0663.99.1.181.

Wood, R., \& Bandura, A. (1989). Social cognitive theory of organizational management. Academy of Management Review, 14, 361-384. doi:10.2307/258173.

Zaidi, A. (2010). A postcolonial sociolinguistics of Punjabi in Pakistan. Journal of Postcolonial Cultures and Societies, Cultures and Societies, 1(3), 22-55.

Yough, M. (2019). Tapping the sources of self-efficacy: Promoting pre-service teachers' sense of efficacy for instructing English language learners, the teacher educator, 54, 206-224. doi: 10.1080/08878730.2018.1534031.

Zimmerman, B. J. (2008). Investigating self-regulation and motivation: Historical background, methodological developments, and future prospects. American Educational Research Journal, 45, 166-183. doi:10.3102/0002831207312909.

Zimmerman, B. J., \& Cleary, T. J. (2009). Motives to self-regulate learning: A social cognitive account. In K. R. Wentzel \& A. Wigfield (Eds.), Handbook of motivation at school (pp. 247-264). New York: Routledge.

Received: May 19, 2019

Accepted: September 07, 2019

PhD, Scholar, Institute of Education and Research, University of the Punjab Lahore,

Pakistan.

E-mail: hassanbhattig@hotmail.com 